\title{
Aspectos Químicos do Envelhecimento
}

\section{Introdução}

$\mathrm{O}$ aparente incremento da longevidade ocorrido durante os últimos séculos nos países civilizados deve-se ao aumento da vida média (por diminuição da mortalidade infantil, melhor alimentação, etc.) e não à extensão do tempo máximo de vida.

Hayflick provou que o número de divisões celulares ocorrido numa dada estirpe é limitado, dependendo da espécie, do órgão e da idade do dador. Apenas as células anormais (por ex. cancerosas) aparentam dividir-se indefidamente.

No início do estudo sistemático dos fenómenos associados ao envelhecimento surgiram teorias gerais que se queriam excluir mutuamente. Tornou-se depois evidente que múltiplos mecanismos de natureza química eram responsáveis pelas manifestações macroscópicas do envelhecimento. O palco habitual desses mecanismos é a célula. Um organismo idoso tem menos células e as que possui funcionam pior que as de um organismo jovem.

\section{Radicais livres e o oxigénio}

Sabe-se hoje que a química do envelhecimento é essencialmente uma química de radicais livres. Estes podem ter várias origens - radiação, poluentes, metabolismo natural - e tornam-se mais nocivos quando há deficiência de compostos protectores.

O oxigénio que, no seu estado fundamental, oxigénio tripleto, $\left({ }^{3} \mathrm{O}_{2}\right)$ é pouco reactivo, é uma fonte de várias formas «activas» radicalares ou não: oxigénio singleto $\left({ }^{1} \mathrm{O}_{2}\right)$, ião superóxido $\left(\mathrm{O}_{2} \bullet \bullet\right)$, peróxido de hidrogénio $\left(\mathrm{H}_{2} \mathrm{O}_{2}\right)$ e radical hidroxilo $(\cdot \mathrm{OH})$.

O oxigénio singleto pode formar-se a partir do oxigénio tripleto por acção da luz ou de sensibilizadores (esquema 1), sendo o efeito da luz particularmente importante no globo ocular.

Durante a redução, no organismo, do oxigénio molecular a água, formam-se espécies tóxicas como o ião superóxido e o peróxido de hidrogénio. Estes podem ainda gerar o radical hidroxilo (ciclo de Haber - Weiss) que é o oxidante mais forte da família do oxigénio (esquema 1). O ião superóxido pode actuar como base, nucleófilo, radical ou reagente de transferência electrónica.
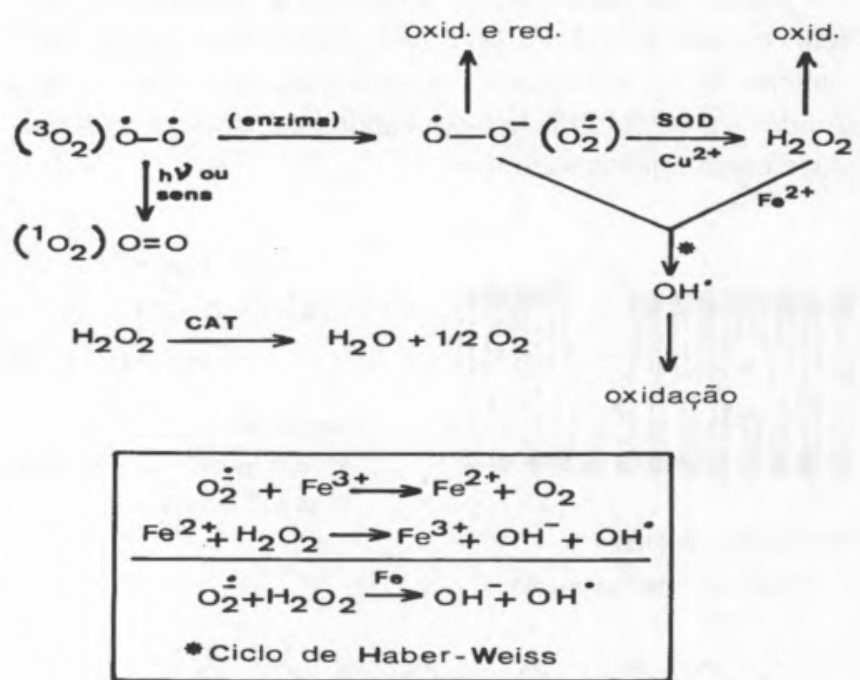

esquema 1

Há, no entanto, sistemas enzimáticos preventivos que neutralizam as formas activas, por exemplo, a superóxido dismutase (SOD), a catalase (CAT) e a glutationa peroxidase (GSH-Px) (esquema 2). Há também outros compostos neutralizadores como por exemplo as vitaminas E e C, ácido úrico, medicamentos, quelantes do ferro e do cobre (ferritina, transferrina, ceruloplasmina).

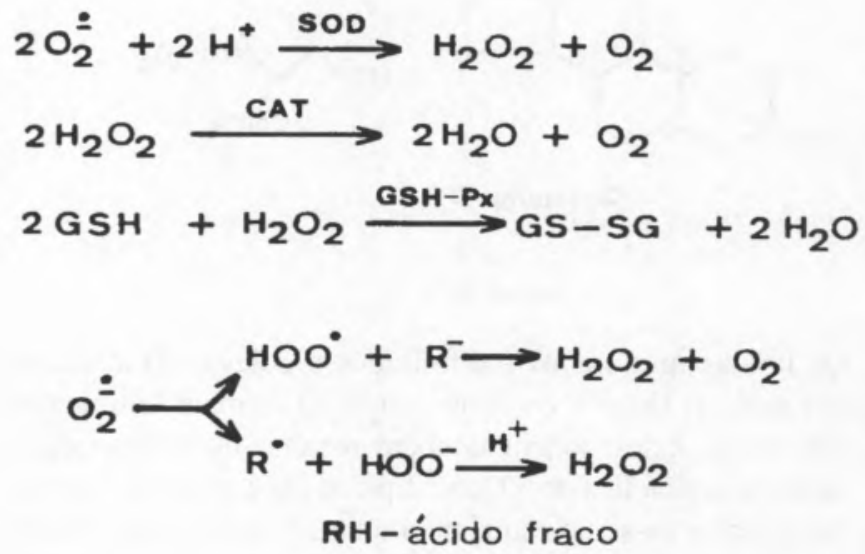

esquema 2

a Centro de Química Pura e Aplicada da Universidade do Minho, Avenida João XXI, 4700 Braga 


\section{Peroxidação dos lípidos}

Em geral, os sinais de ressonância paramagnética electrónica (RPE) mais fortes são detectados em células com elevadas concentrações de mitocôndrias. Nas mitocôndrias há elevada concentração de lípidos e o DNA é mais acessível que o DNA nuclear (porque menos envolvido em proteínas). É também aí que se desenrola o processo respiratório pelo que se formam os radicais derivados do oxigénio $-\mathrm{O}_{2}^{\mathbf{*}} \mathrm{e} \cdot \mathrm{OH}^{\bullet}$. Assim o DNA e os lípidos das mitocôndrias são mais vulneráveis ao ataque desses radicais.

As membranas consistem de lípidos e proteínas (esquema 3) em proporções variáveis, por exemplo, na mitocôndria contêm cerca de $27 \%$ de lípido e $73 \%$ de proteína. $\mathrm{O}$ ataque dos radicais livres aos lípidos das membranas vai alterar a sua fluidez e permeabilidade bloqueando extensamente a actividade enzimática nesse meio.
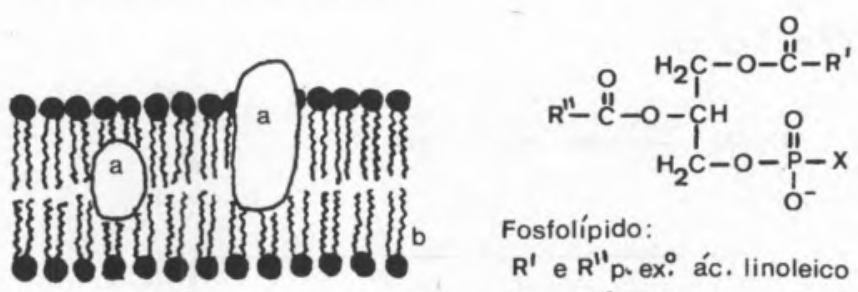

Fosfolípido:

$R^{\prime}$ e $R^{\prime \prime} p$. ex: ác. linoleico

$X$ p. ex: colina

Membrana celular:

$\begin{array}{lll}\text { a) Proteína } & \text { b) Fosfolípido }\end{array}$
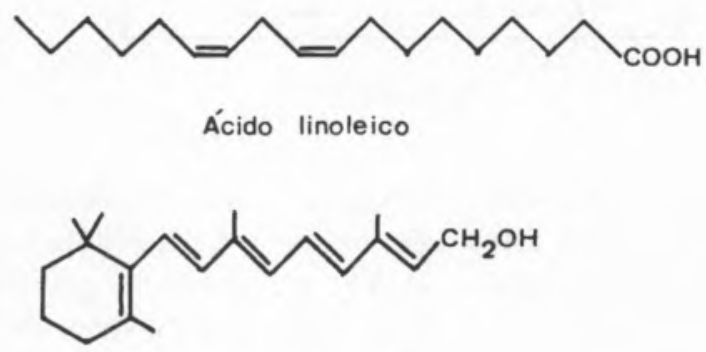

Retinol (vit.A)<smiles>CC(C)CCCC(C)C1CCC2C3CC=C4CC(O)CCC4(C)C3CCC12C</smiles>

Colesterol

esquema 3

Os lípidos insaturados (fosfolípidos e colesterol) atacados por radicais livres e oxigénio (tripleto) formam hidrogenoperóxidos. Estes podem também resultar de uma reacção química pericíclica de ${ }^{1} \mathrm{O}_{2}$ com lípidos insaturados (esquema 4). Representa-se no esquema 4 uma parte da cadeia de um ácido gordo insaturado que sofre peroxidação, bem como a decomposição dos hidrogenoperóxidos formados.

A decomposição dos peróxidos, catalizada por metais de transição (p. ex. Cu) forma radicais que podem propagar a reacção em cadeia. Estes podem ainda decompor-se dando produtos reactivos que perturbam o metabolismo celular.
Um dos produtos finais da decomposição é o aldeído malónico. Podem formar-se ligações cruzadas entre lípidos ou entre lípidos (grupos aldeído) e proteínas (grupos amina).

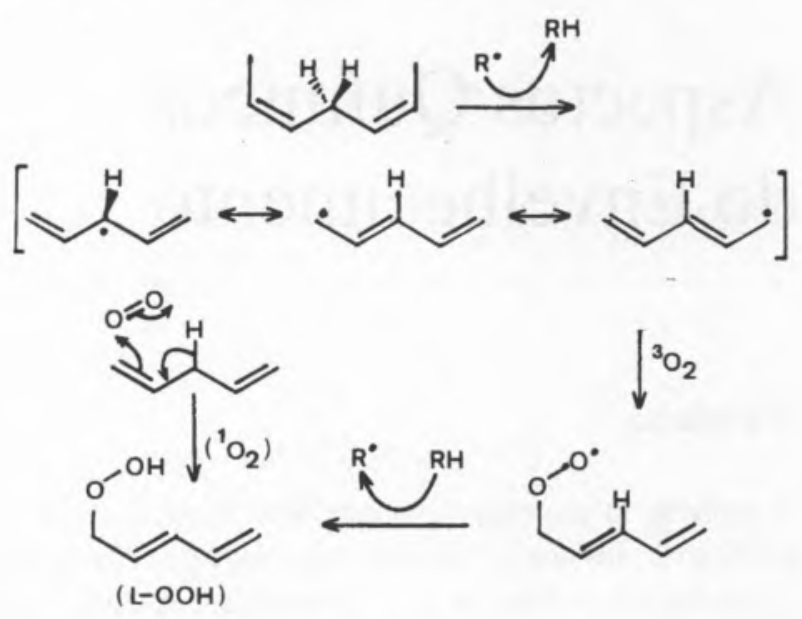

Peroxidação de um ácido gordo insaturado

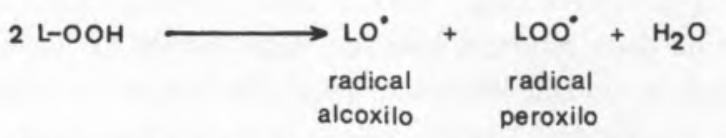

Decomposição dos hidrogenoperóxidos

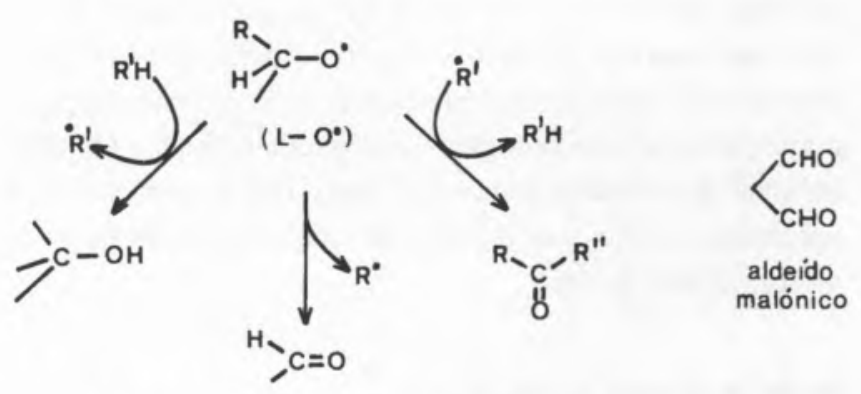

Produtos de decomposição dos lipidos

esquema 4

\section{Sistemas de proteç̧ão}

Já foram mencionados alguns enzimas que tinham a função de neutralizar formas activas de oxigénio como a superóxido dismutase, a catalase e a glutationa peroxidase (GSH-Px). A glutationa é o tripéptido $\gamma$-glutamilcisteilglicina (esquema 5).

A glutationa peroxidase reduz o peróxido de hidrogénio a água e outros peróxidos a alcoóis (esquema 5) e o seu papel é fundamental no cristalino do olho. A deficiência neste enzima (ou no seu cofactor-selénio) implica uma deficiente decomposição dos peróxidos. Observou-se que, em regiões onde a ingestão de selénio é elevada, há menor incidência de certas formas de cancro e de doenças cardiovasculares.

$\mathrm{O} \alpha$-tocoferol (vitamina E) e o ácido ascórbico (vitamina C) são captadores de radicais livres nas fases lipídica e aquosa, respectivamente. A acção antioxidante da vitamina E exercese de dois modos: bloqueia a propagação de radicais por terminação da cadeia (formando radicais mais estáveis) e neutraliza o oxigénio singleto (esquema 5). 
<smiles>Cc1c(C)c2c(c(C)c1O)CCC(C)(CCCC(C)CCCC(C)CCCC(C)C)O2</smiles>

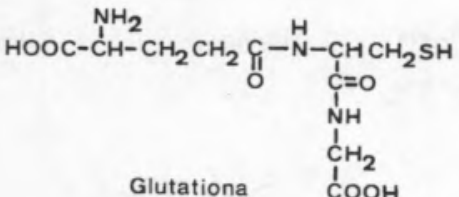<smiles>Cc1cc(Br)cc(C(C)(C)C)c1O</smiles>

LO०

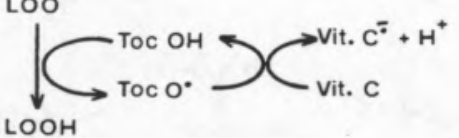

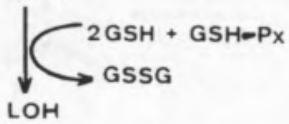

Redução do radical peroxilo

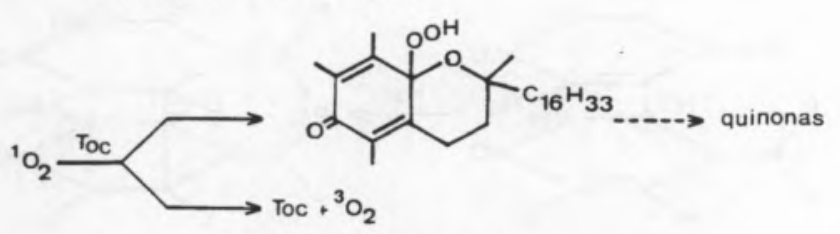

Neutralização do oxigenio singleto<smiles>O=C1C=CC(C=C2C=CC=CC2)C=C1</smiles>

Estabilização do radical fenoxilo

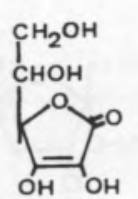

Ácido

L- ascórbico

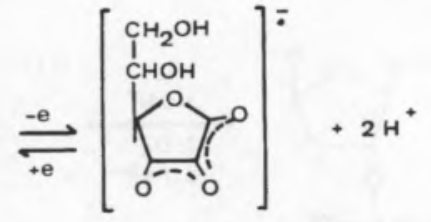

Aniāo radicalar ascorbato

esquema 5
O Homem necessita de ingerir tocoferóis e na sua falta os lípidos mostram efeitos de auto-oxidação. Como se sabe, é obrigatório adicionar vitamina $\mathrm{E}$ a margarinas e óleos para retardar a auto-oxidação e portanto o aparecimento do cheiro a ranço. A 2-mercaptoetilamina (2-MEA) e o butilhidroxitolueno (BHT), por exemplo são aditivos alimentares também com acção antioxidante. Os antioxidantes são também muito importantes no tecido canceroso onde a concentração de tocoferol é muito mais alta que no tecido normal.

$\mathrm{O}$ anião ascorbato (vit. $\mathrm{C}-\mathrm{H}^{+}$) actua sinergisticamente com antioxidantes fenólicos como o $\alpha$-tocoferol. Converte o radical fenoxilo no fenol regenerando assim o antioxidante (esquema 5).

Sabe-se que o $\beta$-caroteno protege as plantas dos efeitos fotodinâmicos destruidores, durante a fotossíntese. Os peróxidos resultantes da oxidação dos lípidos, também destroem os ésteres do retinol. Por isso é aconselhável a ingestão de carotenos, precursores da vitamina $\mathrm{A}$. Esta é necessária à regeneração do pigmento visual dos bastonetes da retina mas também protege o revestimento dos tecidos. Em excesso, porém, a vitamina A é tóxica.

Os compostos de enxofre protegem os componentes celulares dos radicais porque formando radicais (RS•) mais estáveis permitem uma reparação ou impedem a formação de ligações cruzadas (esquema 6). Os tióis e dissulfuretos celulares reparam a maioria dos danos anóxicos, mas, em presença de oxigénio a reacção deste com o radical é mais rápida e para evitar lesões devem adicionar-se compostos com enxofre como a mercaptoetilamina (MEA) e a cisteína, entre outros (esquema 6).

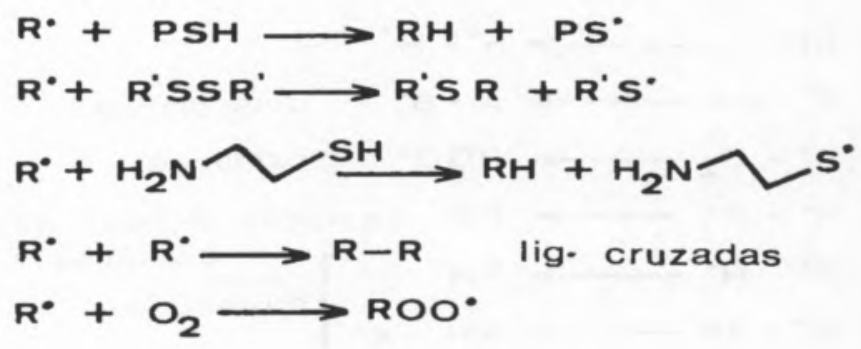

$\mathbf{R}=$ macromolécula<smiles>NCCS</smiles>

PSH = proteína<smiles>NC(CS)C(=O)O</smiles>

Cisteína

esquema 6

Há ainda a referir a existência de enzimas reparadores da membrana. Um deles é a fosfolipase $A_{2}$ que remove ácidos gordos (AG) oxidados dos fosfolípidos da membrana (esquema 7). A perturbação da membrana celular leva à entrada de Cálcio $\left(\mathrm{Ca}^{2+}\right)$ na célula e activa a fosfolipase $\mathrm{A}_{2}$.

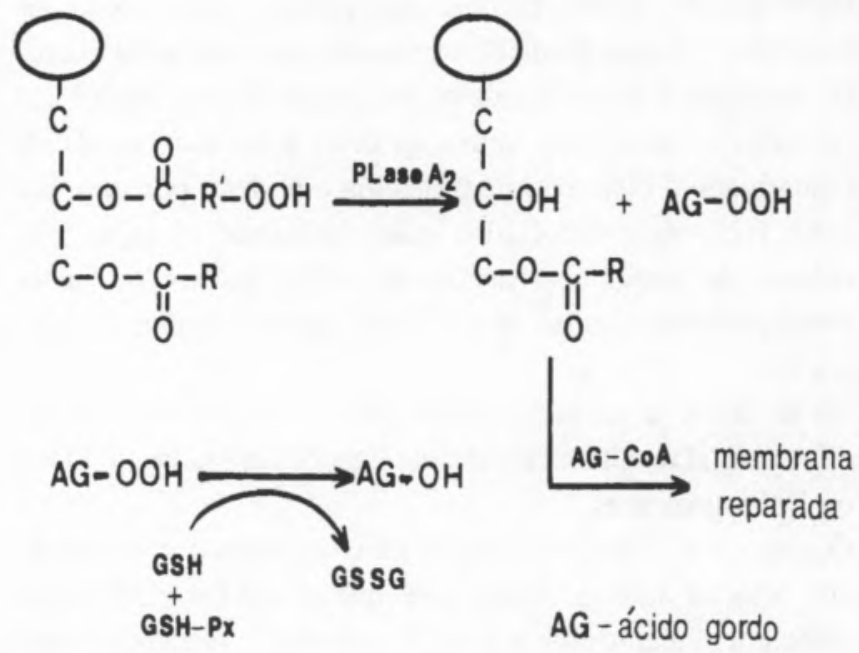

esquema 7 


\section{Efeitos da radiação no DNA}

Os efeitos produzidos por radiações nas células assemelhamse aos que resultam do ataque de radicais livres.

Quando radiação ionizante incide numa célula, pode provocar a ionização directa de macromoléculas $(\mathrm{RH})$. Finalmente os radicais macromoleculares reagem com outras moléculas ou entre si. Apresentam-se algumas reacções típicas (esquema 8). Os três primeiros tipos de reacção implicam muitas vezes a perda (ou distorção) da função biológica. Podem formar-se ligações cruzadas no DNA, nas proteínas, ou DNA-proteína. Não são necessárias muitas colisões com radicais para que um enzima perca a sua actividade biológica.

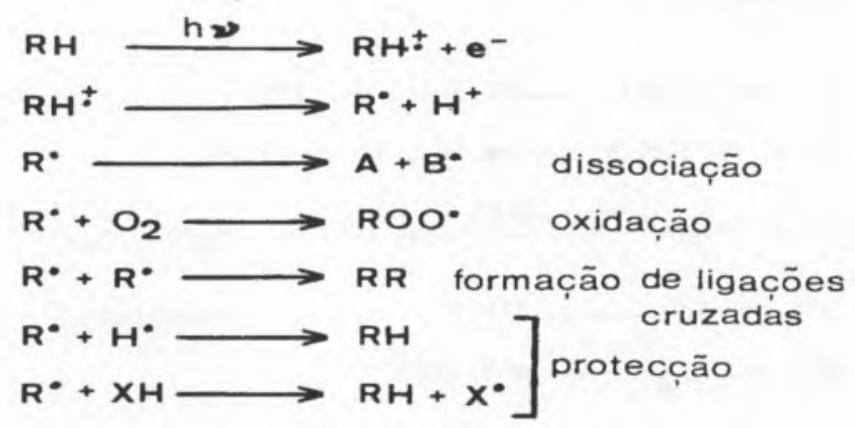

esquema 8

Embora aconteça a ionização directa de macromoléculas, o principal efeito da radiação verifica-se nas moléculas de água uma vez que esta constitui cerca de 70 a $80 \%$ da massa das células. Os iões produzidos por irradiação da água $\left(\mathrm{H}_{2} \mathrm{O}^{+}\right.$ e $\mathrm{H}_{2} \mathrm{O}$ ) dissociam-se e formam $\mathrm{H} \cdot \mathrm{e} \cdot \mathrm{OH}$, espécies muito reactivas e responsáveis por ataques com graves consequências, às macromoléculas. $\mathrm{O}$ radical hidroxilo é o principal «assassino».

De um modo geral, a radiação não produz ligações cruzadas no colagénico mas, antes estimula a sua síntese.

Os principais efeitos letais da radiação ionizante sobre o DNA parecem dever-se também ao radical hidroxilo.

$\mathrm{O}$ ataque ao DNA pode fazer-se às bases ou ao esqueleto. As bases podem sofrer reacções nos grupos exocíclicos, por exemplo, a formação da 8-hidroxiadenina a partir da adenina, resultando daí danos que podem passar despercebidos. As reacções no anel com saturação deste provocam perda de planaridade e distorção da molécula e podem, por isso, ser mais facilmente detectados pelos sistemas de reparação celular. As principais reaç̧ões do radical hidroxilo com as bases parecem resultar de adição às ligações duplas (esquema 9).

Na ausência de oxigénio predomina a reacção dos radicais entre si. Daí resultam certamente ligações cruzadas no DNA ou DNA-proteínas.

Quando um desoxinucleósido (desoxicitidina) é irradiado em solução aquosa, observa-se que o radical $\bullet \mathrm{OH}$ reage preferencialmente com a base. No entanto as reacções com o açucar são importantes porque provocam cortes no esqueleto do DNA. Estas lesões no esqueleto do DNA poderão ser
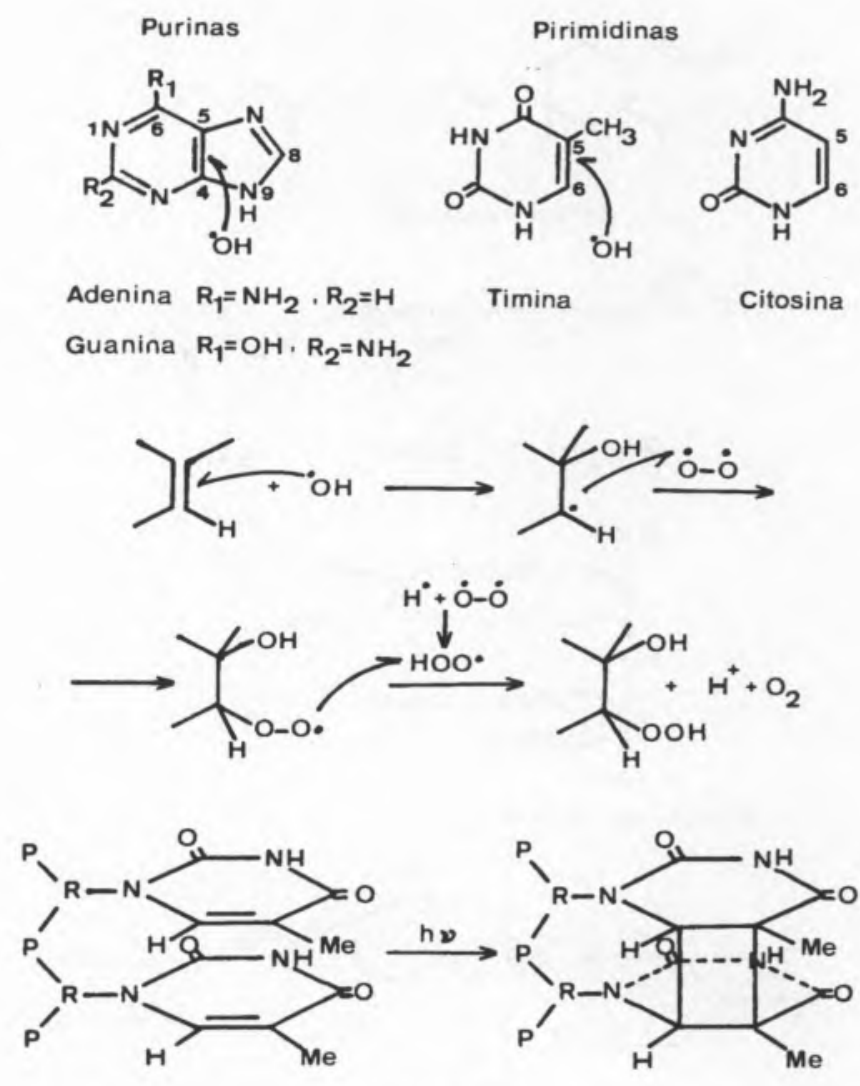

esquema 9

reparadas pela DNA ligase. É provável que o ataque do $\bullet \mathrm{OH}$ comece pela remoção de $\mathrm{H} \bullet$ de um dos carbonos ( $2,3,4$ ou 5 ) do açucar. Os produtos principais correspondem à excisão do açucar mas já foram isolados produtos com açucar danificado ligado a um dos grupos fosfato terminais.
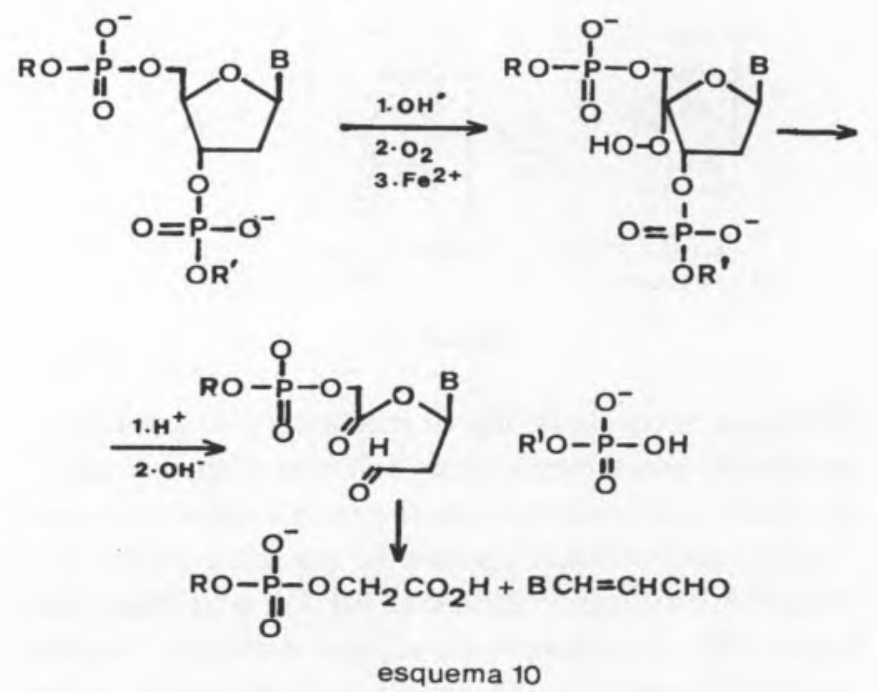

O principal efeito da radiação ultravioleta sobre o DNA consiste na formação de dímeros de pirimidinas, sendo o da timina o que se forma mais facilmente (esquema 9). O sol do meio dia é responsável pela formação destes dímeros nas células da pele expostas à radiação. A existência destes dímeros bloqueia a acção da DNA polimerase e impede a replicação. Há mecanismos de reparação para este tipo de lesão, mas se forem deficientes desenvolve-se cancro da pele. 


\section{Pigmentos da idade}

Uma ligação entre a peroxidação dos lípidos e o envelhecimento encontra-se na química dos pigmentos da idade. Estes materiais, uma espécie de lixo da célula, são compostos castanhos fluorescentes que se acumulam lentamente nas células que não são regularmente substituídas tais como as células não divisíveis do coração, sistema nervoso e pulmões.

Os pigmentos da idade consistem aproximadamente de $60 \%$ de proteína, $25 \%$ lípido e $15 \%$ hidrato de carbono e as reacções radicalares parecem ser importantes na sua produção. Os fragmentos lipídicos apresentam-se peroxidados e as proteínas com ligações cruzadas. Os componentes corados destes pigmentos pertencem em vários casos, aos compostos do tipo da melanina. As melaninas (esquema 11) são redes poliméricas e dão sinal em RPE.

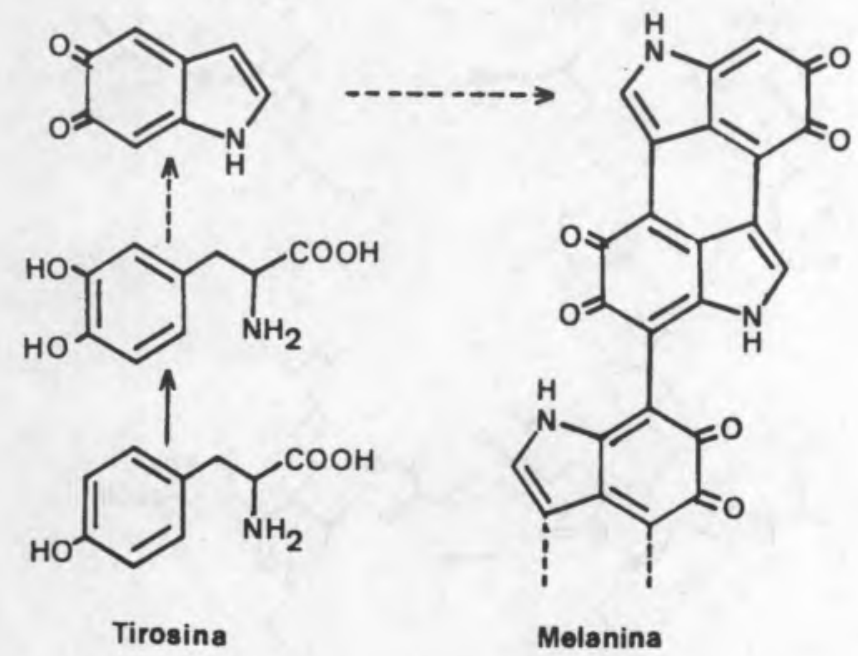

esquema 11

\section{Teoria do deutério}

Foi sugerido que o enriquecimento gradual em deutério (por troca com ${ }_{1}^{2} \mathrm{H}$ existente na água) das moléculas biológicas vai tornar as reacções bioquímicas cada vez mais lentas.

$\mathrm{O}$ equilíbrio ceto-enólico, seguido da redução do grupo carbonilo seria um dos processos de incorporação de deutério em posições em que se tornaria difícil trocá-lo de novo.

Esta teoria poderia explicar a acumulação de pequenos erros, a produção de proteínas imperfeitas e o funcionamento gradualmente mais lento das células.

\section{Colagénio. Ligações cruzadas no colagénio}

O colagénio é a proteína mais vulgar nos animais superiores aparecendo em quase todos os tecidos: pele, tendões, ossos e dentes, vasos sanguíneos, pulmões, cartilagens, válvulas cardíacas, córnea, etc.

A renovação do colagénio é muito lenta na maior parte dos tecidos adultos, por isso, alterações progressivas da estrutura do colagénio (por exemplo, aumento das ligações cruzadas) vão reflectir-se no modo como esses tecidos vão actuar.
Como foi referido já, as moléculas de colagénio apresentam funções diversas e por isso têm de diferir na constituição química. De facto, o colagénio descreve uma «família» de moléculas (pelo menos cinco tipos geneticamente distintos) que têm em comum uma tripla hélice direita de 3 subunidades polipeptídicas que são hélices esquerdas (figura).

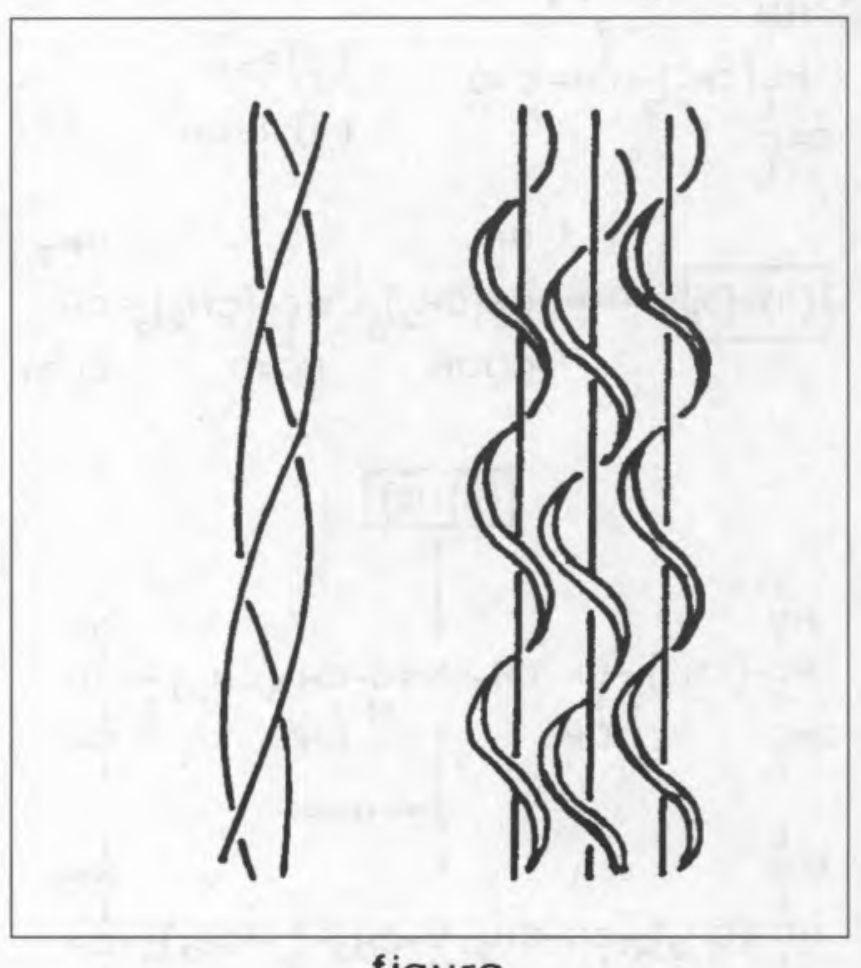

figura

No colagénio há muita glicina (cerca de $20 \%$ ), prolina, 4hidroxiprolina e 5-hidroxilisina, outros resíduos de aminoácidos modificados e galactose ou $\beta$-glucosilgalactose associadas à hidroxilisina. A rigidez da tripla hélice (denominada tropocolagénio) deriva das restrições conformacionais impostas pela prolina e hidroxiprolina e a sua estabilidade das ligações de hidrogénio que estes aminoácidos podem estabelecer.

Dentro de cada tipo genético de colagénio continua a existir heterogeneidade química. Diferenças na composição em aminoácidos modificados, no grau de hidroxilação, no conteúdo de açucar e de ligações cruzadas dependem da função do tecido, da idade e do estado hormonal do indivíduo.

Embora se disponha apenas de 20 aminoácidos para construir as proteínas, identificaram-se cerca de 140 aminoácidos e seus derivados como constituintes de proteínas diferentes, em vários organismos. Isso é devido a modificações que esses aminoácidos sofrem depois da fase de tradução. Algumas reacções de modificação têm lógica porque tornam possíveis determinados processos biológicos, outras continuam sem explicação. Exemplos dessas reaç̧ões são: a hidroxilação de resíduos de prolina e lisina, a reaç̧ão da hidroxilisina com açúcares e a conversão das cadeias laterais de lisina e hidroxilisina em aldeídos. Esta última conversão é uma desaminação oxidativa catalizada pela lisina oxidase (esquema 12). 

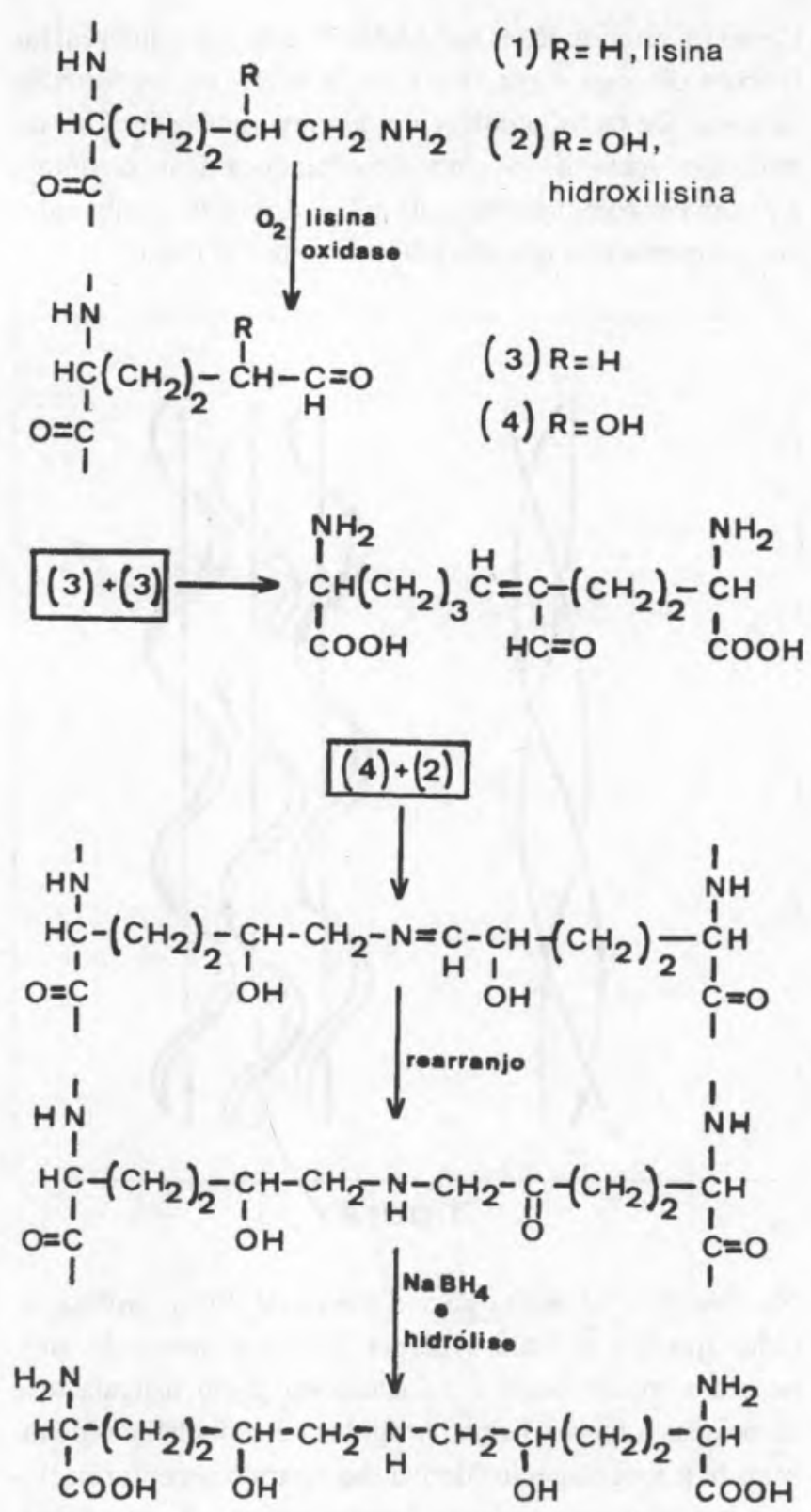

dinidroxilisinonorleucina

esquema 12

Podem surgir vários tipos de ligações cruzadas no colagénio, sendo os grupos amina e aldeído os principais responsáveis. Por isso as reacções mais frequentes são a condensação aldólica e a formação de bases de Schiff e também a adição de Michael.

A maior parte dos aminoácidos envolvidos nessas ligações cruzadas foram identificados por redução com Na B ${ }_{1}^{3} \mathrm{H}_{4}$ seguida de hidrólise ácida e cromatografia de troca iónica. Dão-se alguns exemplos de ligações cruzadas. No esquema 12 apresenta-se uma ligação cruzada de tipo aldol que é abundante nos tendões e na pele.

A dihidroxilisinonorleucina (DHLNL) é o principal composto marcado com trítio quando se trata colagénio do osso ou cartilagem com $\mathrm{Na} \mathrm{B}_{1}^{3} \mathrm{H}_{4}$. Esta ligação cruzada deriva de dois resíduos de hidroxilisina e é bastante estável mesmo antes da redução porque a aldimina inicial rearranja a uma cetamina. A maior parte do composto surge glicosilado (como derivados galactosilo ou glucosilgalactosilo).
As ligações cruzadas redutíveis desaparecem gradualmente dos tecidos conjuntivos adultos, o que sugere que são intermediários com vida longa mas que podem ainda reagir. Surgem assim novas ligações cruzadas que podem isolar-se sem recorrer a redução prévia. Um exemplo disso é a ligação cruzada - desmosina - na elastina (esquema 13). Recentemente foi isolada do colagénio uma ligação cruzada fluorescente que é um composto de 3-hidroxipiridínio que se supõe derivar de 3 resíduos de hidroxilisina (esquema 13). Provouse que este composto se torna mais abundante com a idade, enquanto a dihidroxilisinonorleucina (DHLNL) diminui, o que sugere que seja este o precursor.
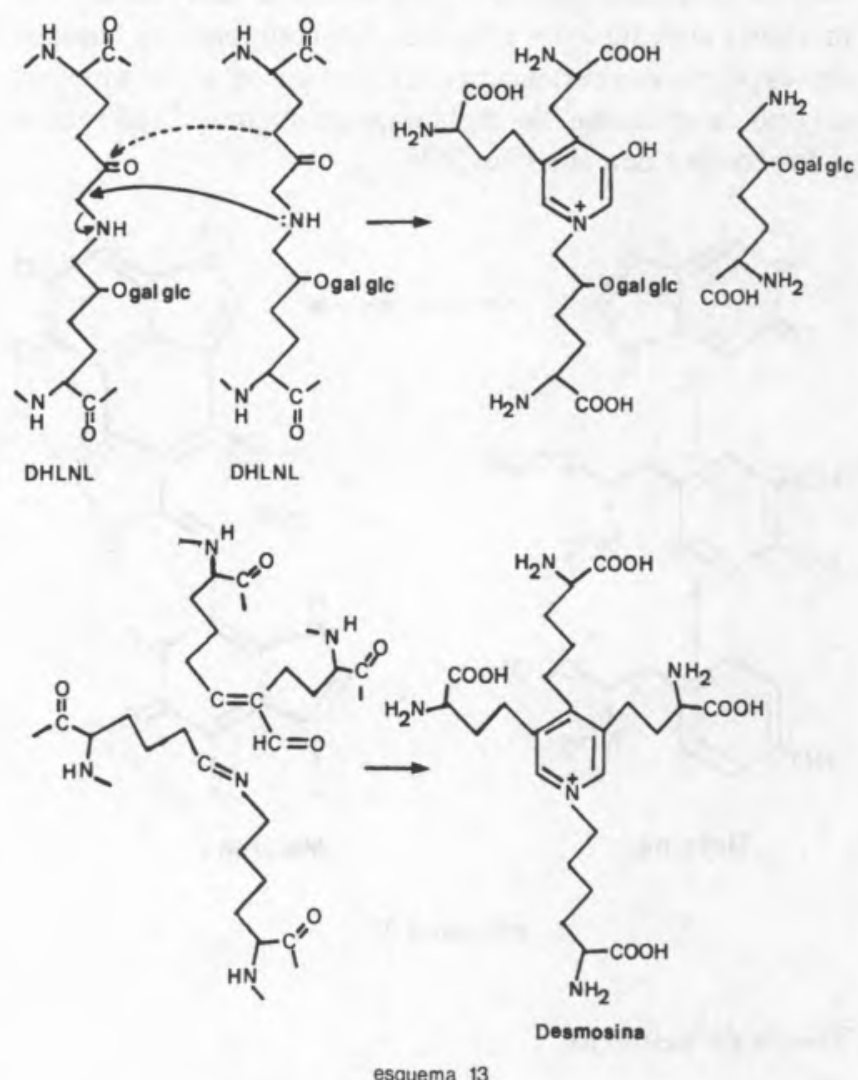

Mencionam-se em último lugar as ligações cruzadas envolvendo açucares. Os açucares podem formar bases de Schiff com os grupos $\mathrm{NH}_{2}$ disponíveis nas proteínas (e. g. lisina) e foram isolados do colagénio vários desses produtos (na forma reduzida).

A base de Schiff inicialmente formada tautomeriza e converte-se no chamado produto de Amadori (esquema 14). Alguns destes produtos sofrem desidratação e rearranjos, lentamente, dando estruturas estáveis de cor castanha amarelada e fluorescentes. Às vezes dois produtos de Amadori podem reagir entre si formando ligações cruzadas. A ligação 2-furanil-4(5)-(2-furanil)-1H-imidazola (FFI) foi encontrada no corpo humano. Assim, a ligação química da glucose (ou outros açúcares) a proteínas pode provocar alterações permanentes nestas e contribuir para o envelhecimento. Encontra-se nos diabéticos uma maior quantidade de produtos de Amadori. $\mathrm{O}$ efeito da diabetes em muitos órgãos e tecidos é semelhante a um envelhecimento acelerado pois as complicações resultantes (cataratas, aterosclerose e rigidez das articulações) são idênticas às dos idosos. 


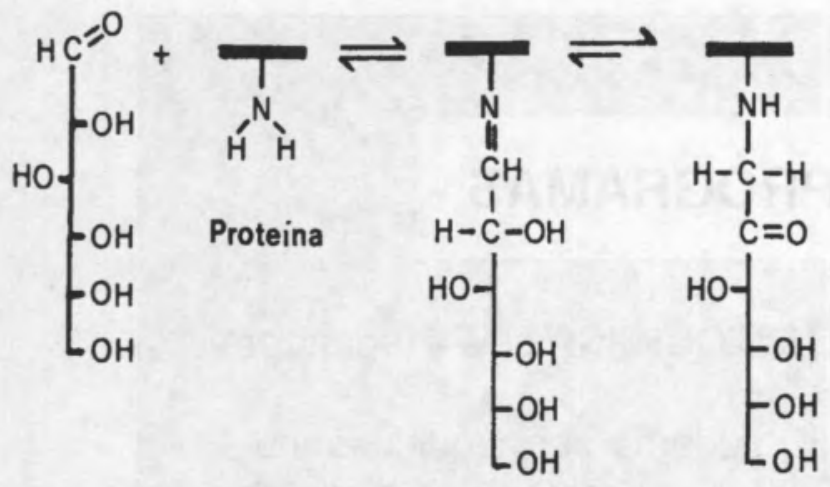

Glucose

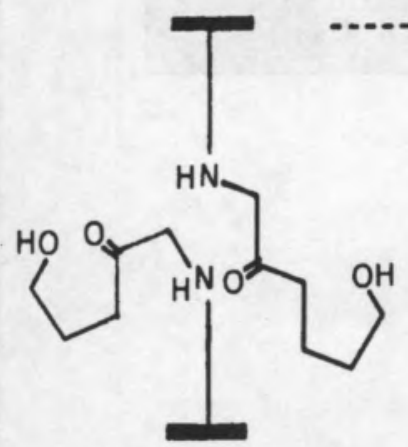

Produtos de Amadori

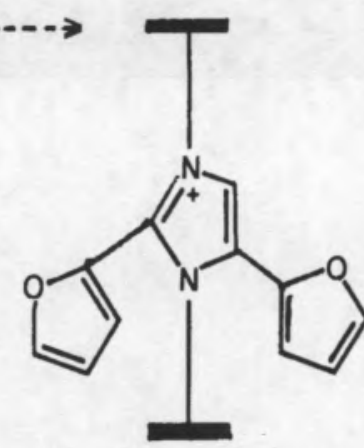

Ligação cruzada (FFI) esquema 14

Supõe-se que o colagénio alterado pela glucose facilita ainda a formação de ligações dissulfureto e a retenção de lipoproteínas de baixa densidade que se vão acumulando nas placas ateroscleróticas.

\section{Referências}

Ligaçōes cruzadas no colagénio

- D. R. Eyre, Science, 1980, 207, 1315-1322.

- B. W. Bycroft and A. A. Higton in «The Chemistry of Natural Products», ed. R. H. Thomson, Blackie, Glasgow, 1985, 285-288.

- T. P. Coultate, «Food, the Chemistry of its components», R. S. C. Paperbacks, London, 1984, 93-95.

- M. L. Tanzer, Science, 1973, 180, 561-566.

Ligaçöes cruzadas/glucose

- A. Cerami, H. Vlassara and M. Brownlee, Sci. Amer., 1987, May, 82-88.

Deutério

- T. R. Griffiths, Mechanisms of Ageing and Development, 1973, 2, 295-307.

Radicais livres

- R. Nudd and D. Wilkie, Chem. Brit., 1983, 19, (11), 911-913.

- D. T. Sawyer, Chem. Tech., 1988, 369-375.

- G. Scott, Chem. Brit., 1985, 648-653.

- T. P. Coultate, «Food, the Chemistry of its components», Royal Society of Chemistry paperbacks, London, 1984, 93-94, 42-68.

- F. J. G. M. van Kuijk, A. Sevanian, G. J. Handelman and E. A. Dratz, Trends in Biochem. Sciences, 1987, 12, 31-34.

- L. Paker and J. Walton, Chem. Tech., 1977, 276-281.

- D. Harman in «Free radicals in Biology", W. A. Prior (ed.), vol 5, chap. 8, Academic Press, New York, 1982.

- J. F. Ward, J. Chem. Educ., 1981, 58 (2), 135-9.

- R. L. Clough, B. G. Yee and C. S. Foote, J. Am. Chem. Soc., 1979, 101 (3), 683.

- C. W. Lawrence, «Cellular Radiobiology», Edward Arnold Publ. Ltd., London, 1971.

- M. B. Davies, I. J. S. Fiddes and D. A. Partridge, Educ. Chem., 1986, March, 39-42.

- L. Giloni, M. Takeshita, F. Johnson, C. Iden and A. P. Grollman, J. Biol. Chem., 1981, 256 (16), 8608-8615.

\section{Bibliografia Geral}

- J. J. R. Fraústo da Silva, «Introdução à Química da Vida», Universidade Nova de Lisboa, 1985.

- L. da Silva Campos, «Manual de Bioquímica», Publicações Europa-América.

\section{ELEVENTH \\ INTERNATIONAL CONFERENCE ON CHEMICAL EDUCATION}

25-30 August 1991

University of York

York, U.K.

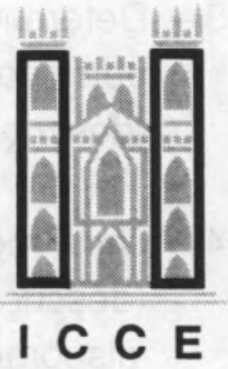

\section{BRINGING CHEMISTRY TO LIFE}

Organizado pelo Commitee on Teaching of Chemistry da International Union of Pure and Applied Chemistry e a Royal Society of Chemistry em conjugação com a UNESCO e a ASE.

Para mais informações contactar: Dr. J.F. Gibson

The Royal Society of Chemistry

Burlington House, Piccadilly

London W1V OBN

Grã-Bretanha 


\section{BIBLIOTECA DE PROGRAMAS}

A secção temática COMPUTADORES EM QUÍMICA está a organizar UMA BIBLIOTECA DE PROGRAMAS.

Os programas (em disquetes de 5.25 ") poderão ser adquiridos mediante o envio de um cheque de $500 \$ 00$ (para pagamento da disquete e portes de Correio) dirigido à Sociedade Portuguesa de Química.

PROGRAMAS DISPONIVEIS:

1 - Simulação de uma Curva de Titulação

Ácido Fraco - Base Forte

(descrição no Bol. Soc. Port. Quím., 1985, 22, 67)

2 - Determinação Computacional da Temperatura Crítica Superior de Solução de uma Mistura Líquida Binária

(descrição no Bol. Soc. Port. Quím., 1988, 34, 19)

3 - Determinação Computacional de Funções Termodinâmicas de Activação a partir da Equação de Everett e Wynne-Jones

(descrição no Bol. Soc. Port. Quím., 34, 19)

4 - Um Programa de Cálculo do Modelo de Hückel em Microcomputador (descrição no Bol. Soc. Port. Quím., 1986; 33, 26;

dispomos de versões para os micros Apple lle e Apple llc e encontra-se já em preparação uma versão destinada a ser utilizada com MS-DOS) 